\title{
Calcareous nannofossils and sedimentary facies in the Upper Cretaceous Bozeş Formation (Southern Apuseni Mountains, Romania)
}

\author{
Ramona BĂLC1,*, Lóránd SILYE² \& Luminița ZAHARIA² \\ ${ }^{1}$ Faculty of Environmental Sciences and Engineering, Babeș-Bolyai University, Fântânele 30, 400294 Cluj-Napoca, Romania \\ ${ }^{2}$ Department of Geology, Babeş-Bolyai University, Kogălniceanu 1, 400084 Cluj-Napoca, Romania
}

Received November 2011; accepted January 2012

Available online 31 January 2012

DOI: $10.5038 / 1937-8602.57 .1 .3$

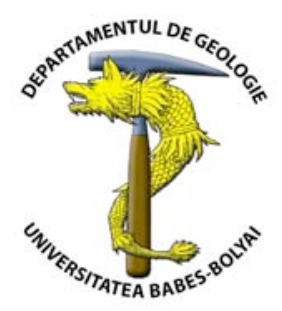

\begin{abstract}
The lithology, sedimentology and biostratigraphy of the Bozeş Formation, which crop out in the SE Metaliferi Mountains (Apuseni Mts.) have been investigated in order to establish the age of the deposits and the depositional environment. The sedimentary structures and facies are interpreted as indicating a deep-water depositional environment, representing part of a submarine fan lobe. Three facies assemblages have been identified and described. Calcareous nannofossils were used to determine the age of the investigated deposits. The presence of Lucianorhabdus cayeuxii and Calculites obscurus indicates the CC17 biozone, while UC13 Zone is pointed out by the continuous occurrence of Arkhangelskiella cymbiformis and the absence of Broinsonia parca parca. Thus, the age of the studied deposits is Late Santonian -?Early Campanian.
\end{abstract}

Key words: sedimentary facies, fan-lobe, calcareous nannofossils, Santonian-Campanian boundary, Bozeş Formation, Apuseni Mountains.

\section{INTRODUCTION}

The studied area is located in the SE part of the Metaliferi Mountains (Apuseni Mts.), bordered by the Ampoi Valley at $\mathrm{N}$ and by the Mureş Valley at SE (Fig. 1). During the Late Cretaceous, the present-day SE area of the Metaliferous Mts. was part of a basin in which siliciclastic material was deposited in a turbiditic facies. These deposits crop out extensively along the rivers that run NE-SW, all tributaries to the Mureş River. The main goals of this study were to identify specific sedimentary facies of these deposits and interpret their depositional environment, and to establish their precise chronostratigraphy. To achieve these, interpretation of the sedimentary structures and determination of the calcareous nannofossils assemblages were involved.

\section{GEOLOGICAL SETTING}

The Apuseni Mountains originated from the Preapulian Craton (Săndulescu, 1994) and the Transylvanian Tethys (Săndulescu, 1984). They include two major tectonic units: the Transylvanides and the Apusenides. Three deformation periods, i.e. Austrian (Aptian-Albian), Pregosau (intra-Turonian) and Laramian (Maastrichtian-Danian) affected the Apuseni Mountains (Bleahu et al., 1981). The Transylvanides were emplaced during the Austrian tectonic phase and reworked during the Laramian one. The Pregosau tectonic phase sheared only the Apusenides (Bleahu et al., 1981; Balintoni, 1997).

Tectonically, the Bozeş Nappe represents the uppermost unit among the western Transylvanides and it crops out in the southern Apuseni Mountains. The main litostratigraphical component of this nappe is known as the Bozeş Formation *Correspondence: R. Bălc (ramona.balc@ubbcluj.ro)
(Ghițulescu and Socolescu, 1941). Early studies (Ianovici et al., 1976; Bordea et al., 1978; Bleahu et al., 1981; Săndulescu, 1984) considered this formation, along with the Bobâlna and Geoagiu Formations, as constituting the Bozeş Nappe, all three lithostratigraphical units being interpreted as a unitary posttectonic Cretaceous cover of Austrian Transylvanides Căbeşti, Căpâlnaş-Techereu and Ardeu. More recently, Balintoni (2003) grouped within the frame of the Bozeş Nappe, the Bozeş Formation together with the Bejan Formation and the Rapolt and Poiana Ruscă crystalline units, and described them as tectonically related to the Southern Carpathians.

Lithologically, the Bozeş Formation consists of rhythmically alternating clays and sandstones, with an overall thickness of 3000m (Ghițulescu and Socolescu, 1941). There are two distinct units: (a) a binary one, constituted by sub-greywacke sandstones and sandy limestones interbedded with gray marls; and (b) a ternary unit, with alternating micro-conglomerates, gray sandstones and marls (Ghițulescu and Socolescu, 1941).

Antonescu et al. (1973) constrained the transport direction of the detrital material based on the identified erosional structures on the sandstone surfaces, and provided a detailed lithological characterization of the formation. Based on these data, three facies types were described from west to east: (a) flysch, (b) marine molasse (conglomerates and marls) and (c) continental molasse (mainly conglomerates). Bleahu and Dimian (1963) also contributed with data on the lithology and paleocurrent direction.

Studying the macro- and microfauna content, several authors (Dimian and Popa-Dimian, 1964; Marincaş and Mânecan, 1971; Marincaş, 1973; Bălc et al., 2007) proposed a Santonian Campanian - early Maastrichtian age for the Bozeş Formation. 

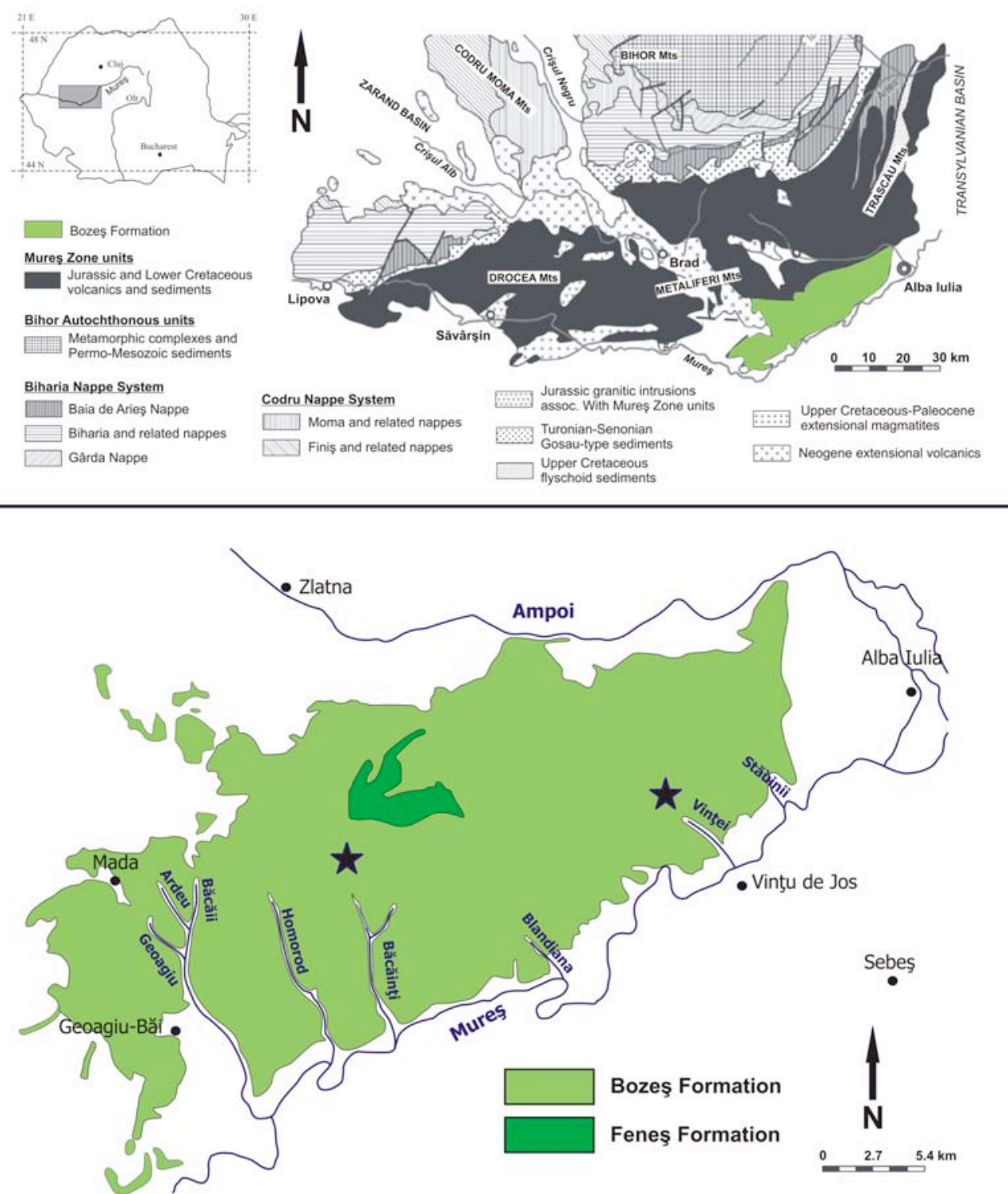

Fig. 1. Sketch of the main Alpine tectonic units in the Southern Apuseni Mts, showing the location of the Bozeş Formation (after Balintoni et al., 2009) (upper part) and enlarged map of the Bozeş Formation, with location of the studied valleys (marked with black stars) (after Geological maps of Romania, 1: 200.000, Turda and Orăştie sheets) (lower part).

\section{MATERIALS AND ANALYTHICAL METHODS}

Several exposures along the Băcăinți and Vința valleys were studied in order to describe the most characteristic sedimentary facies of the Bozeş Formation. The outcrops were systematically sampled to determine the calcareous nannoplankton content.

Due to the local geological conditions, the studied outcrops are small (at most about 10-20 meters high, and several 10 meters wide) and the strata have dip direction/dip $114^{\circ} / 50^{\circ}$ in the Băcăinți Valley and $110^{\circ} / 30^{\circ}$ in Vința Valley. Therefore the stratigraphic order of the outcrops separated by larger hiatuses is 1-3 on Băcăinți Valley and 4-5 from Vința Valley.

The studied sections were measured through the stratigraphy at centimeter scale. Sedimentary structures and the textural features of the sedimentary record were observed and described in detail along exposures and layer surfaces following the methods used by Pickering et al. (1986) and Umar et al. (2011). Then the sedimentary facies were grouped in facies association to constrain the deposition environment. Synthetic high-resolution graphic logs were drawn using StratDraw ver. 13 (Hoelzel, 2004) to identify any possible depositional cycles and to get clues on their stacking pattern.
To describe the calcareous nannoplankton assemblages, thirty-eight samples from Băcăinți outcrops and twenty-nine from Vința ones were analyzed. Sample preparation was made according with standard methods (Bown and Young, 1998). A semi-quantitative study of the collected samples was performed. In addition, two longitudinal traverses for each sample were read to identify the rare species. The age determination was achieved using the biozone charts of Sissingh (1977), Perch-Nielsen (1985) and Burnett (1998).

\section{SEDIMENTOLOGY: FACIES AND FACIES ASSOCIATION}

The most important sedimentological feature of the studied outcrops from both valleys is the quite monotonous packages of centimeter to at most decimeter thick mudstones or siltstones interbedded with centimeter or usually decimeter thick fine to medium sandstones (Fig. 2 and 3). The following sedimentary facies have been identified:

(a) F1 comprises of laterally continuous, commonly normal graded or massive sandstones with or without Bouma 
sequence, containing flutes (Fig. 4) and/or grooves and/or load (Fig. 5) structures at the base. Bed thickness is laterally continuous at outcrop scale and ranges between several $10 \mathrm{~cm}$ and at most meters (Fig. 6).

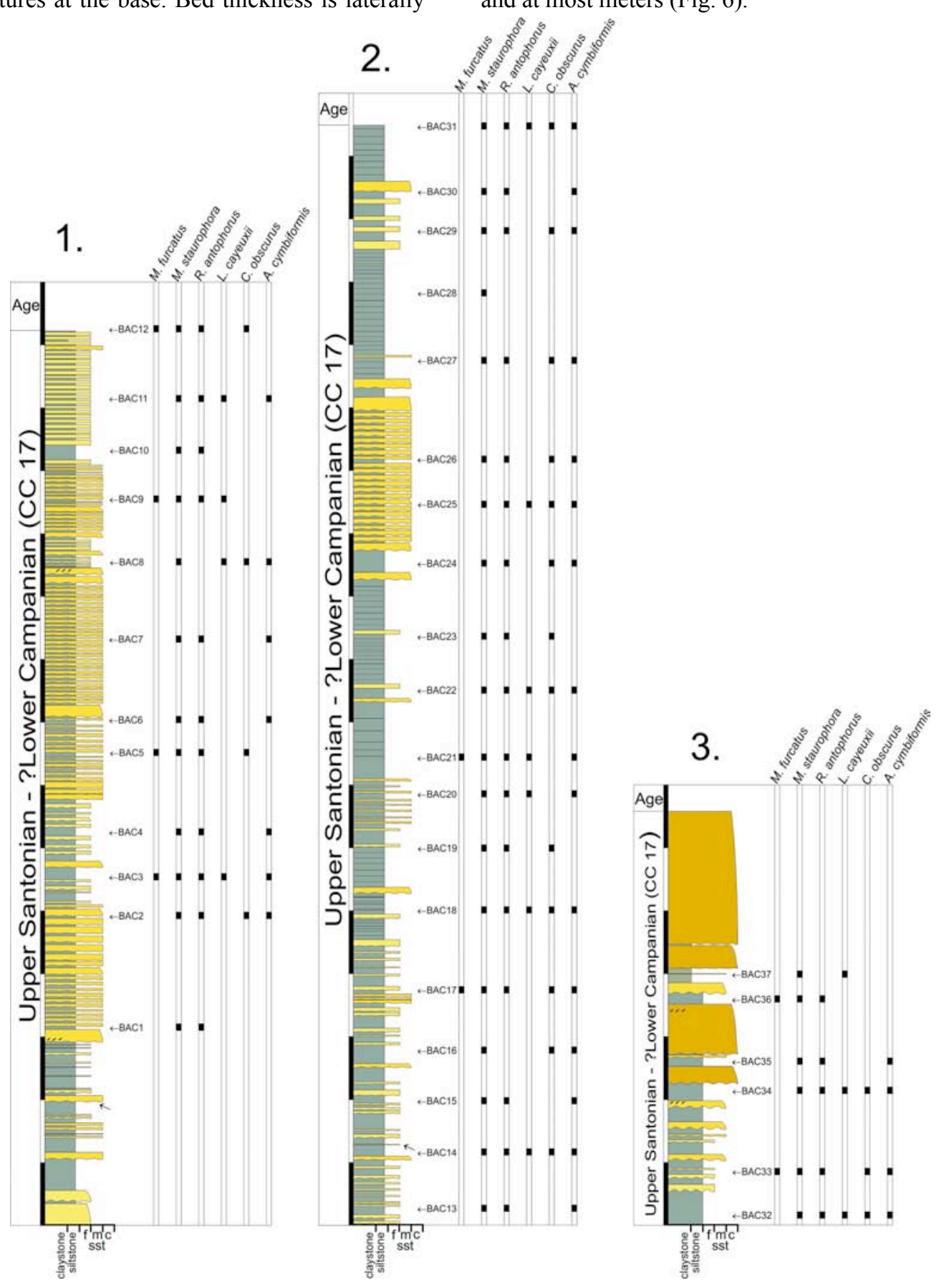

Fig. 2. Logs of Băcăinţi sections (1 to 3). The age, biozone, and range of the identified calcareous nannofossils are mentioned. A scale unit represents $1 \mathrm{~m}$.

The sandstones may contain shelly rip-up clasts, and rare dewatering structures may be present. The beds show Tab (most commonly), whereas thicker beds show Ta or Tab Bouma sequences.

According to Johnson et al. (2001) and Umar et al. (2011), based on the characteristics of the thick beds and the scour structures at the base of sandstone beds, F1 may be interpreted as deposited from high-density turbidity currents.

(b) F2 is represented by mudstones or siltstones alternating with sandstones (Fig. 7). The mudstone/siltstone is centimeter to at most decimeter thick, parallel laminated or stratified, fissile and only at same places slightly bioturbated. The sandstone is fine (most commonly) to medium grained, usually thin bedded (most commonly 5-8 cm) with erosional lower boundaries, massive or parallel laminated and/or rarely cross laminated showing $\mathrm{Tb}$ or Tbc Bouma type sequences.

The mudstones/siltstones of F2 were deposited by low density turbiditic currents whereas the sandstones were interpreted as products of low energy turbiditic currents, based on similarities with Facies Group C2 in Pickering et al. (1986) and facies FJ in Umar et al. (2011).

(c) F3 consists of mudstones or siltstones with rare massive or graded sandstones. Several decimeters thick laminated to thin bedded mudstone/siltstone packages with rare thin (at most centimeter thick) fine-grained sandstone beds. This facies underlies both F1 and F2 facies (Fig. 5) and was deposited by low velocity and low-density turbidity currents (similar with lithofacies 1 in Johnson et al., 2001 or facies FK in Umar et al., 2011). 


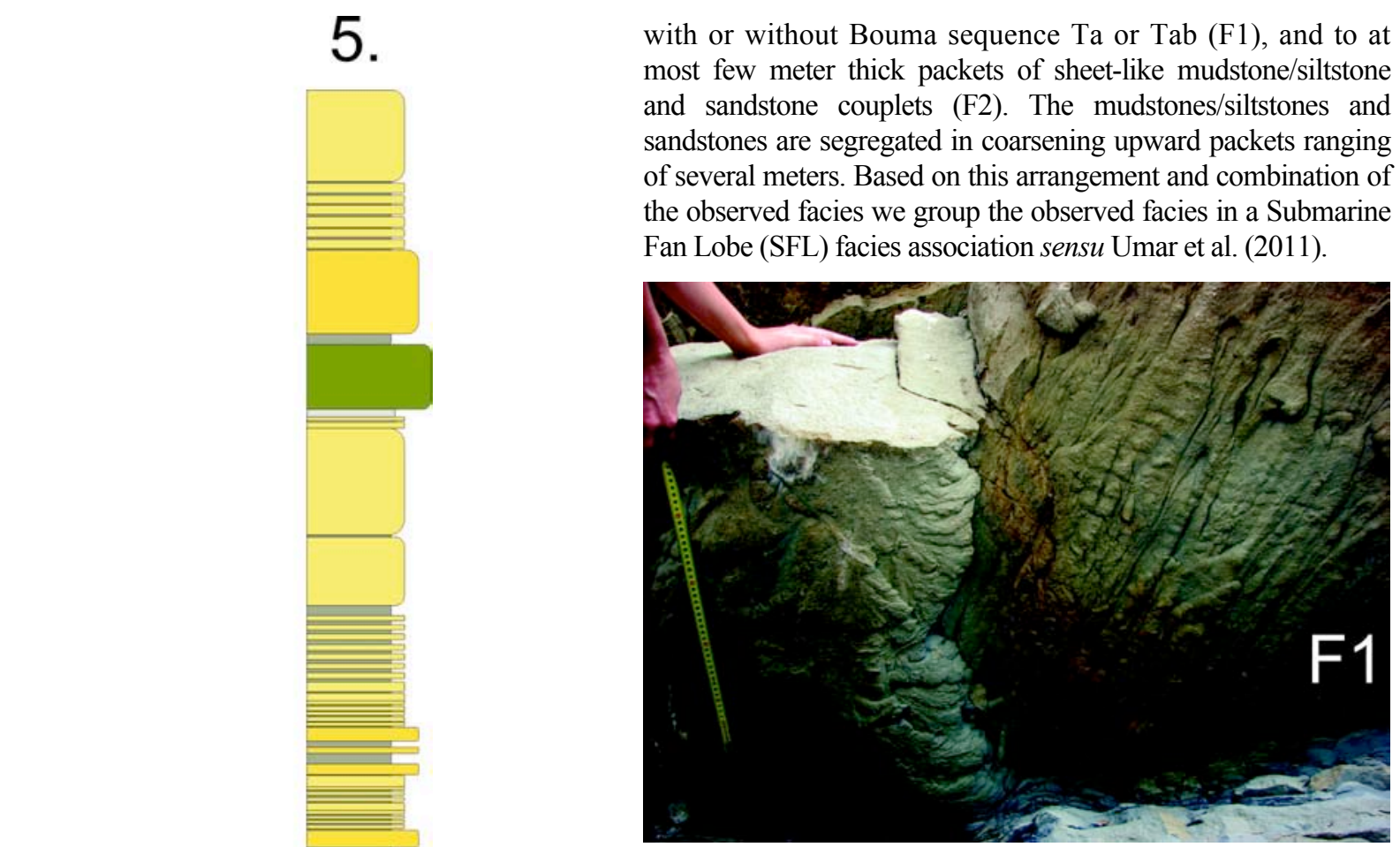

Fig. 4. Field photograph showing flutes at the base of continuous sandstones (F1 facies, profile 3, Băcăinţi Valley).

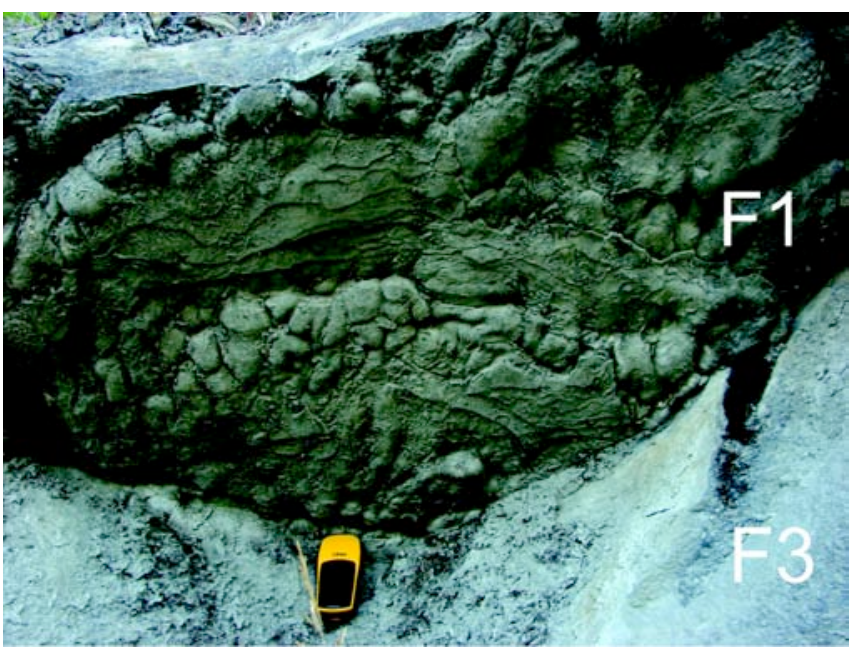

Fig. 5. Field photograph showing load structures at the base of sandstone (F1 facies, profile 1, Băcăinţi Valley).

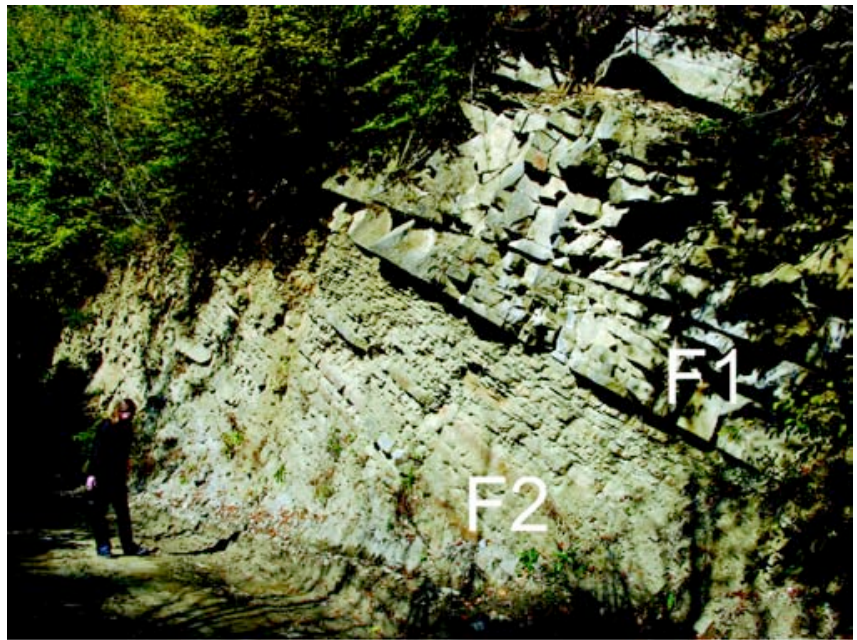

Fig. 6. Field photograph showing laterally continuous turbidites of the F1 and F2 facies (profile 5, Vinţa Valley). continuous, commonly normal graded or massive sandstones Studia UBB Geologia, 2012, 57 (1), 23 - 32 

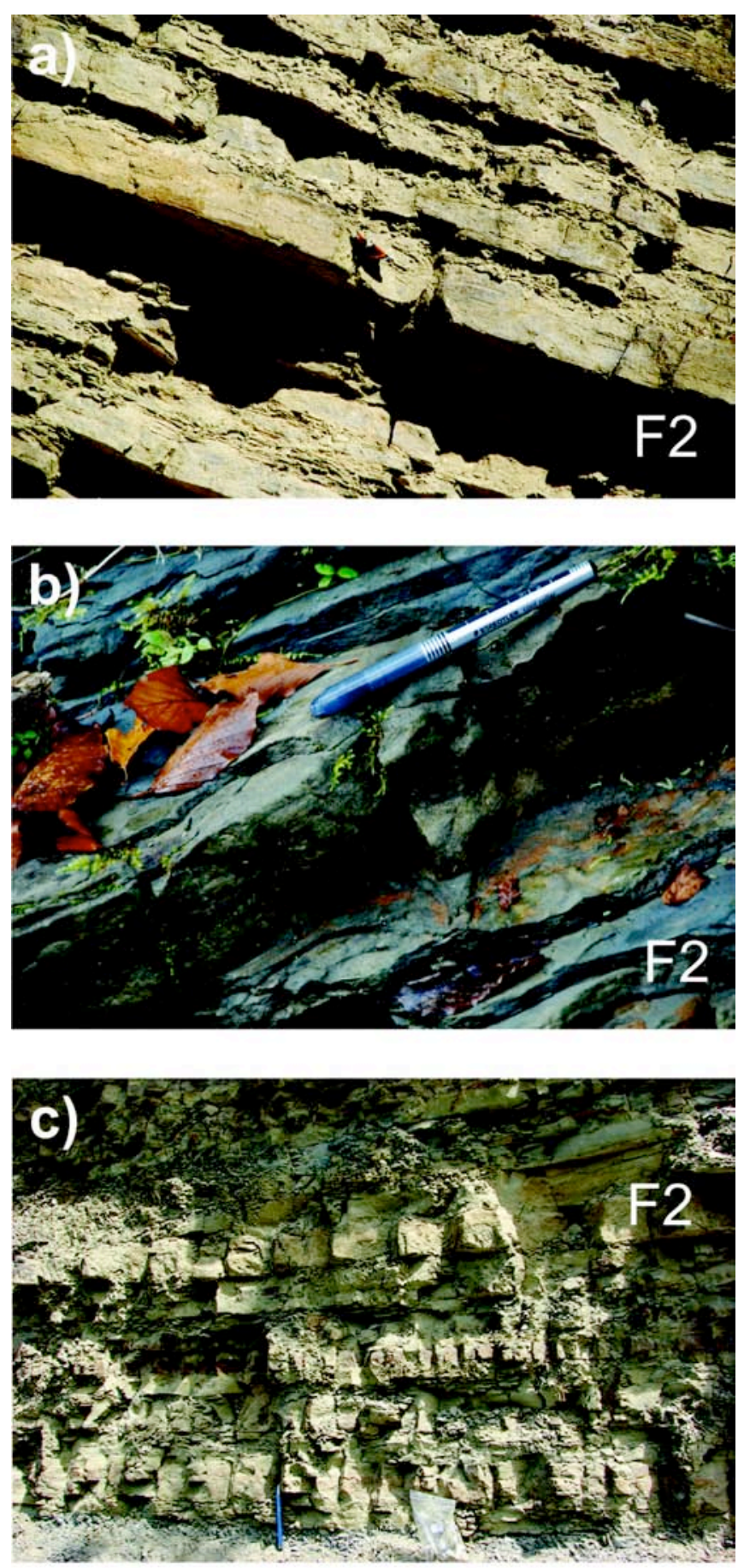

Fig. 7. Field photographs showing the alternating mudstone and sandstone layers of facies F2: a) profile 5 and b) profile 4 (Vinţa Valley), c) profile 3 (Băcăinţi Valley).

\section{CALCAREOUS NANNOPLANKTON}

The semiquantitative study of calcareous nannofossils from the Băcăinți Valley outcrops reveals a rich and diversified assemblage. The preservation state is high good to moderate in the case of the first two sections (1 and 2), and moderate to poor in the latter section (3). Due to the lack of calcareous nannofossils and/or the presence of undetermined fragments or long-ranging taxa, it was not possible to establish the age of the sedimentary deposits from the Vinta Valley. Therefore, the following discussion will refer only to the Băcăinți samples.

Sixty-three species have been identified in total. The list of all identified species is given in the Appendix, while some representative taxa are illustrated in Plate 1. A range chart of some important Santonian species is given in Fig. 2.

The most abundant species is Watznaueria barnesae, followed by Prediscosphaera cretacea (between 3.75\% and $11.22 \%$ ), Tranolithus orionatus (between $1.94 \%$ and $11 \%$ ), Retecapsa crenulata (between $3.18 \%$ and $8.49 \%$ ), Eiffelithus eximius (between $1.98 \%$ and $11 \%$ ) and Cribrosphaerella ehrenbergii (between 1.93\% and 10.66\%). The abundance of Watznaueria barnesae varies between $30 \%$ and $56 \%$ (exceeding $40 \%$ in 15 samples from the 38 analyzed). An increase in its abundance in the upper part of the third section can be seen, exactly where Micula staurophora also exhibits an increase in abundance. The latter taxon appears in reduced numbers but continuously in the rest of the sections (varying between $0.59 \%$ and $18.66 \%$ ). As Watznaueria barnesae and Micula staurophora usually correlate negatively in the Upper Cretaceous successions (Eshet and Almogi-Labin, 1996), this increasing in abundance of both taxa can be interpreted as a signal of increasing diagenesis. However, the moderate abundance of some dissolution-susceptible taxa such as Tranolithus orionatus (Paul et al., 1999) or Prediscosphaera spinosa (Thierstein, 1980; Henriksson and Malmgren, 1999) demonstrates that the calcareous nannofossil assemblage from the studied deposits is well preserved and diverse, being slightly affected by dissolution.

Micula staurophora is a dissolution-resistant taxon (Thierstein, 1980; Eshet and Almogi-Labin, 1996), in some cases forming monospecific assemblages (Eshet and Almogi-Labin, 1996).

Watznaueria barnesae is an abundant species in Cretaceous environments, being capable to adapt to fluctuating and/or extreme conditions (Mutterlose, 1991). Thus, when its relative abundance exceeds ca. $40 \%$, it indicates a strongly altered assemblage (Roth and Krumbach, 1986), in environments with oligotrophy/low fertility (Roth and Bowdler, 1981; Erba, 1992; Herrle, 2003). In their study of Upper Jurassic deposits from the Kimmeridge Clay Formation, Lees et al. $(2004,2005)$ have demonstrated that Watznaueria barnesae indicates an eutrophic environment. Melinte-Dobrinescu and Bojar (2008) suggest that the high abundance of Watznaueria barnesae points out an open marine environment, increased nutrients, ecological instability, and probably mesotrophy rather than poor preservation rates of the calcareous nannofossil assemblage.

Sporadically, other taxa have been observed in the analyzed sample, as (a) Russelia bukryi and Russelia laswelii, species mentioned from Maastrichtian deposits (Burnett, 1998) or (b) Ahmuelerella octoradiata, Kamptnerius magnificus and Gartnerago segmentatum, mentioned mainly as high-latitude, cold waters taxa (Wind, 1979; Thierstein, 1976, 1981; Burnett, 1998; Švábenická, 2001; Lees 2002). But, because of the low amount of these taxa in the studied section, a cooling episode or a cold water influx in the Tethyan Realm cannot be sustained.

The Santonian-Campanian boundary is still much disputed. The bioevents marking this boundary are not globally corelabile. The biozonation schemes of Sissingh (1977) modified by Perch-Nielsen (1985) placed the boundary in the upper part of the $\mathrm{CC} 17$ biozone below the FO of Broinsonia parca parca (base of CC18 biozone). Most of the studies identified the FO of this taxon in Lower Campanian (Cunha et al., 1997; Burnett, 1998; Hampton et 
al., 2007; Gale at al., 2008; Melinte-Dobrindescu and Bojar, 2010), at different stratigraphic levels above the SantonianCampanian boundary.

Wagreich (1992) subdivided the CC17 biozone into three subzones separated by the FO of the subspecies Lucianorhabdus cayeuxii - Lucianorhabdus cayeuxii species $\mathrm{B}$, with curved rod - and the LO of Corollithion signum. As in the studied samples, these two species appear sporadically but continuously, they cannot be used to subdivide the CC17 biozone.

In the biozonation scheme of Burnett (1998) the Santonian-Campanian boundary is traced in the uppermost part of UC12, below the FO of Arkhangelskiella cymbiformis, which defines the base of UC13 Zone (Lower Campanian). However, as in some sites, this taxon was identified much lower, in the Upper Santonian (Hampton et al., 2007, Gale et al., 2008; Melinte-Dobrinescu and Bojar, 2010), the base of UC13 Zone should fall within Upper Santonian.

The presence of Lucianorhabdus cayeuxii and Calculites obscurus together with the absence of Broinsonia parca parca indicate that the studied section falls exclusively within CC17 biozone (Sissingh, 1977; Perch-Nielsen, 1985). Based on the continuous presence of the Arkhangelskiella cymbiformis, the section is part of the UC13 Zone of Burnett (1998). Thus, the studied deposits are Late Santonian in age, possible Early Campanian.

\section{CONCLUSIONS}

The facies of the Bozeş Formation suggest a deep-water depositional environment. We interpreted the studied sedimentary units as part of a coarsening and thickeningupward muddy and sandy (middle?)-fan lobe deposited by low-density (mudstones/siltstones) and high-density, but low velocity (sandstones) turbidity currents. The coarser and thicker sandstones of the Vința Valley's exposures may suggest a proximal depositional environment compared to the Băcăinți Valley's section. Alternatively, the outcrops of both valleys can be interpreted as parts of the same stacked large-channel complexes in distal depositional environment (see Johnson et al., 2001).

Based on calcareous nannoplankton, the deposits from the Băcăinți Valley were included in the $\mathrm{CC} 17$ biozone and UC13 Zone respectively. Thus, an Late Santonian - ?Early Campanian age was assigned to the studied section.

Acknowledgments. This study was financially supported by CNCSIS-UEFISCSU, project PN II-RU TE 313/2010. Thanks are due to Mr. Alin Igrițan (Babeş-Bolyai University, Cluj-Napoca) for part of the computer-assisted drawings and those who joined us in the field trip: Adriana Socaciu, Ramona Chelaru and Eugen Prjeslavschi. Mike Kaminski (King Fhad University of Petroleum and Minerals, Saudi Arabia) kindly reviewed a draft of the manuscript. We thank two anonymous reviewers for their corrections and suggestions.

\section{R E F E R E N C E S}

Antonescu, E.M. 1973, Palinologic assemblages characteristic to some Cretaceous formations from Metaliferous Mountains. Dări de seamă ale Institutului Studia UBB Geologia, 2012, 57 (1), 23 - 32 de Geologie, LIX (3): 115-169 (in Romanian).

Balintoni, I. 1997, Geotectonic of the metamorphic terrains from Romania. Ed. Carpatica, Cluj-Napoca, 176 p. (in Romanian).

Balintoni, I. 2003, Towards an improved model of the Laramian Transylvanides. Studia UBB Geologia, Special Issue, 13-20, Cluj-Napoca.

Balintoni, I., Balica, C., Cliveți, M., Li, Q-L., Hann, H.P., Chen, F. \& Schuller, V. 2009, The emplacement age of the Muntele Mare Variscan granite (Apuseni Mountains, Romania). Geologica Carpathica, 60 (6): 495-504. http://dx.doi.org/10.2478/v10096-009-0036-x

Bălc, R., Suciu-Krausz, E. \& Borbei, F. 2007, Biostratigraphy of the Cretaceous deposits in the Western Transylvanides from Ampoi Valley (Southern Apuseni Mountains, Romania). Studia UBB Geologia, 52 (2): 37-43. http://dx.doi.org/10.5038/1937-8602.52.2.5

Bleahu, M., Dimian, M. 1963, Stratonimic characters of cretaceous series from Metaliferi Mountains. Asoc. Geol. Carp.-Balc., Congr. V (1961), III/1: 81-95, Bucharest (in Romanian).

Bleahu, M., Bordea, S., Lupu, M., Ştefan, A., Patrulius, D. \& Panin, S. 1981, The structure of the Apuseni Mountains. Guide to Excursion B3, XII Congress of the CarpathoBalkan Geological Association, Bucharest, $107 \mathrm{p}$.

Bordea, J., Berbeleac, I., Borcoş, M., Mantea, G., Stancu, J. \& Țăranu-Rogge, E. 1978, Explanatory note of geological map of Romania, scale 1:50.000, Geoagiu sheet. Institutul de Geologie şi Geofizică, Bucharest (explanatory note).

Bown, P.R., Young, J.R. 1998, Introduction. In Calcareous nannofossil biostratigraphy (Bown P.R., Ed.), British Micropaleontology Society Series, Chapman \& Hall, London, p. 1-15. http://dx.doi.org/10.1007/978-94-011-4902-0 1

Burnett, J.A. 1998. Upper Cretaceous. In Calcareous nannofossils biostratigraphy (Bown P.R., Ed.), British Micropaleontology Society Series, Chapman \& Hall, London, p. 132-199. http://dx.doi.org/10.1007/978-94-011-4902-0 6

Cunha, A.S., Antunes, R.L. \& Burnett, J.A. 1997, Calcareous nannofossils and the Santonian/Campanian and Campanian/ Maastrichtian boundaries on the Brazilian Continental Margin: historical overview and state of the art. Cretaceous Research, 18: 823-832. http://dx.doi.org/10.1006/cres.1997.0089

Dimian, E., Popa-Dimian, M. 1964, Stratigraphical and sedimentological data regarding the cretaceous formations between Mureşului and Ampoiului Valley. Dări de seamă ale Institutului de Geologie, L/1 (19611963): 107-130 (in Romanian).

Erba, E. 1992, Middle Cretaceous calcareous nannofossils from the western Pacific (Leg 129): evidence for paleoequatorial crossings. College Station, TX: Ocean Dilling Project. Proceedings of the ODP, Scientific Results, 129: 189-201.

Eshet, Y., Almogi-Labin, A. 1996, Calcareous nannofossil as paleoproductivity indicators in Upper Cretaceous organicrich sequences in Israel. Marine Micropaleontology, 29: 37-61. http://dx.doi.org/10.1016/0377-8398(96)00006-0

Gale, A.S., Hancock, J.M., Kennedy, W.J., Petrizzo, M.R., Lees, J.A., Walaszczyk, I. \& Wray, D.S. 2008, An integrated study (geochemistry, stable oxygen and carbon isotopes, nannofossils, planktonic foraminifera, 
inoceramid bivalves, amoonites and crinoids) of the Waxahachie Dam Spillway section, north Texas: a possible boundary stratotipe for the base of the Campanian Stage. Cretaceous Research, 29: 131-167. http://dx.doi.org/10.1016/j.cretres.2007.04.006

Ghițulescu, T.P., Socolescu, M. 1941, Etude geologiques et miniere des Monts Metalliferes. Anuarul Institutului Geologic, XXI: 181-463.

Hampton, M.J., Bailey, H.W., Gallagher, L.T., Mortimore, T.N. \& Wood, C.J. 2007, The biostratigraphy of Seaford Head, Sussex, southern England: an international reference section for the basal boundaries for the Santonian and Campaian Stages in chalk facies. Cretaceous Research, 28: 46-60. http://dx.doi.org/10.1016/j.cretres.2006.05.025

Henriksson, A.S., Malmgren, B.A. 1999, Ranking of differential dissolution of terminal Cretaceous calcareous nannofossils using a statistical approach. Revista Espanola de Micropaleontologia, 31: 289-296.

Herrle, J.O. 2003, Reconstructing nutricline dynamics of mid-Cretaceous oceans: evidence from calcareous nannofossils from the Niveau Paquier black shale (SE France). Marine Micropaleontology, 47: 307-321. http://dx.doi.org/10.1016/S0377-8398(02)00133-0

Hoelzel, M. 2004, StratDraw: automatic generation of stratigraphic sections from tabulated field data. Computers \& Geociences, 30 (7): 785-789. http://dx.doi.org/10.1016/j.cageo.2004.05.004

Ianovici, V., Borcoş, M., Bleahu, M., Patrulius, D., Lupu, M., Dimitrescu, R. \& Savu, H. 1976, The geology of the Apuseni Mountains. Ed. Acad. R.S.R., Bucharest, 631 p.

Johnson, S.D., Flint, S., Hinds, D. \& Wickens, H.D.V. 2001, Anatomy, geometry and sequence stratigraphy of basin floor to slope turbidite systems, Tanqua Karoo, South Africa. Sedimentology, 48 (5): 987-1023.

http://dx.doi.org/10.1046/j.1365-3091.2001.00405.x

Lees, J.A. 2002, Calcareous nannofossil biogeography illustrates paleoclimate change in the Late Cretaceous Indian Ocean. Cretaceous Research, 23: 537-634. http://dx.doi.org/10.1006/cres.2003.1021

Lees, J.A., Bown, P.R., Young, J.R. \& Riding, J.B. 2004, Evidence for annual records of phytoplankton productivity in the Kimmeridge Clay Formation coccolith stone bands (Upper Jurassic, Dorset, UK). Marine Micropaleontology, 52: 29-49. http://dx.doi.org/10.1016/j.marmicro.2004.04.005

Lees, J.A., Bown, P.R. \& Young, J.R. 2005, Upper Cretaceous calcareous nannofossil biostratigraphy, ODP Leg 198 (Shatsky Rise, Northwest Pacific Ocean). Proceedings of the ODP, Scientific Results, 198: 1-60. http://dx.doi.org/10.2973/odp.proc.sr.198.114.2005

Lupu, M. 1983, The mesozoic history of the South Apuseni Mountains. Anuarul Institutului de Geologie si Geofizica, LX: 115-124.

Marincaş, V. 1973, The age of Bozeş beds. Studia UBB Geologia, 1: 39-46 (in Romanian).

Marincaş, V., Mânecan, D. 1971, Contributions a la stratigraphie du cretace superieur dans la region de Geoagiu. Sargetia, VIII: 21-37.

Melinte-Dobrinescu, M.C., Bojar, A.-V. 2008, Biostratigraphic and isotopic record of the Cenomanian-Turonian deposits in the Ohaba-Ponor section (SW Hateg, Romania). Cretaceous Research, 29: 1024-1034. http://dx.doi.org/10.1016/j.cretres.2008.05.018
Melinte-Dobrinescu, M.C., Bojar, A.-V. 2010, Late Cretaceous carbon- and oxygen isotope stratigraphy, nannofossil events and paleoclimate fluctuations in the Hațeg area (SW Romania). Paleogeography, Palaeoclimatology, Palaeoecology, 293: 295-305. http://dx.doi.org/10.1016/j.palaeo.2009.06.020

Mutterlose, J. 1991, Das Verteilungs- und Migrationsmuster des kalkigen Nannoplanktons in der borealen Unter Kreide (Valangin-Apt) NW-Deutschlands. Palaeontographica (B) 221: 27-152.

Paul, C.R.C., Lamolda, M.A., Mitchell, S.F., Vaziri, M.R., Gorostidi, A. \& Marshall, J.D. 1999, The CenomanianTuronian boundary at Eastbourne (Sussex, UK): a proposed European reference section. Palaeogeography, Palaeoclimatology, Palaeoecology, 150: 83-121. http://dx.doi.org/10.1016/S0031-0182(99)00009-7

Perch-Nielsen, K. 1985, Cenozoic calcareous nannofossils. In: Plankton Stratigraphy (Bolli, H.M., Saunders, J.B., Perch-Nielsen, K., Eds.), Cambridge University Press, Cambridge, p. 427-554.

Pickering, K., Stow, D., Watson, M. \& Hiscott, R. 1986, Deep-water facies, processes and models: a review and classification scheme for modern and ancient sediments. Earth-Science Reviews, 23 (2): 75-174. http://dx.doi.org/10.1016/0012-8252(86)90001-2

Roth, P.H., Bowdler, J. 1981, Middle Cretaceous calcareous nannoplankton biogeography and oceanography of the Atlantic Ocean. In: The Deep Sea Drilling Project: a Decade of Progress, Society of Economic Paleontologists and Mineralogists Special Publication 32 (Warme, J.E., Douglas, R.G., Winterer, E.L., Eds.), p. 517-546. http://dx.doi.org/10.1016/0377-8398(86)90031-9

Roth, P.H., Krumbach, K.R. 1986, Middle Cretaceous calcareous nannofossil biogeography and preservation in the Atlantic and Indian Oceans: implication for paleoceanography. Marine Micropaleontology, 10: 235-266.

Săndulescu, M. 1984, Geotectonics of Romania, Ed. Tehnică, Bucharest, 336 p. (in Romanian).

Săndulescu, M. 1994, Overview on Romanian Geology. Romanian Journal of Tectonics and Regional Geology, 75(2): 3-15.

Sissingh, W. 1977, Biostratigraphy of Cretaceous calcareous nannoplankton. Geol. Mijnbouw, Den Haag, 56: 37-65.

Švábenická, L. 2001, Late Campanian/Late Maastrichtian penetration of high-latitude calcareous nannoflora to the Outer Western Carpathian depositional area. Geologica Carpathica, 52 (1): 23-40

Thierstein, H.R. 1976, Mesozoic calcareous nannoplankton biostratigraphy of marine sediments. Marine Micropaleontology, 1: 325-362. http://dx.doi.org/10.1016/0377-8398(76)90015-3

Thierstein, H.R. 1980, Selective dissolution of Late Cretaceous and earliest Tertiary calcareous nannofossils: experimental evidence. Cretaceous Research, 2: 165-176. http://dx.doi.org/10.1016/0195-6671(80)90023-3

Thierstein, H.R. 1981, Late Cretaceous nannoplankton and the change at the Cretaceous-Tertiary boundary, SEPM Special Publication. 32: 355-394.

Umar, M., Khan, A.S., Kelling, G. \& Kassi, A.M. 2011, Depositional environments of Campanian-Maastrichtian successions in the Kirthar Fold Belt, southwest Pakistan: Tectonic influences on late cretaceous sedimentation across the Indian passive margin. Sedimentary Geology, 237(1-2): 30-45. 
http://dx.doi.org/10.1016/j.sedgeo.2011.02.001

Wagreich, M. 1992, Correlation of Late Cretaceous calcareous nannofossil zones with ammonite zones and planktonic Foraminifera: the Austrian Gosau section. Cretaceous Research, 13: 505-516. http://dx.doi.org/10.1016/0195-6671(92)90014-H

Wagreich, M., Summesberg, H. \& Kroh, A. 2010, Late Santonian bioevents in the Schattau section, Gosau Group of Austria - implications for the Santonian-Campanian boundary stratigraphy. Cretaceous Research, 31: 181-191. http://dx.doi.org/10.1016/j.cretres.2009.10.003
Wind, F.H. 1979, Maastrichtian-Campanian nannofloral provinces of the southern Atlantic and Indian Oceans. In Deep Drilling Results in the Atlantic Ocean: Continental Margins and Paleoenvironment (Talwani, M., Hay, W., Ryan, W.B.F. (Eds.), American Geophysical Union, Washington, p. 123-137. http://dx.doi.org/10.1029/ME003p0123

*** 1967, Geological Map of Romania, 1:200.000, Turda Sheet, Geological Institute, Bucharest.

*** 1968, Geological Map of Romania, 1:200.000, Orăştie Sheet, Geological Institute, Bucharest.

Plate I. Calcareous nannofossils from the Băcăinți Valley section. The photographs taken under parallel and crossed polars. The sample number is given in brackets.

1. Arkhangelskiella cymbiformis Vekshina, 1959 (33)

2. Ahmuellerella octoradiata (Górka, 1957) Reinhardt, 1966 (2)

3. Ahmuellerella regularis (Górka, 1957) Reinhardt \& Górka, 1967 (33)

4. Braarudosphaera bigelowii (Gran \& Braarud, 1935) Deflandre, 1947 (15)

5. Chiastozygus amphipons (Bramlette \& Martini, 1964) Gartner, 1968 (11)

6. Chiastozygus bifarius Bukry, 1969 (33)

7. Cribrosphaerella ehrenbergii (Arkhangelsky, 1912) Deflandre in Pivetteau, 1952 (33)

8. Calculites obscurus (Deflandre, 1959) Prins \& Sissingh in Sissingh, 1977 (33)

9. Calculites ovalis (Stradner, 1963) Prins \& Sissingh in Sissingh, 1977 (33)

10. Corollithion signum Stradner, 1963 (15)

11. Cylindralithus sculptus Bukry, 1969 (2)

12. Eiffelithus eximius (Stover, 1966) Perch-Nielsen, 1968 (4)

13. Eiffelithus gorkae Reinhardt, 1965 (33)

14. Eiffelithus turriseiffelii (Deflandre in Deflandre \& Fert, 1954) Reinhardt, 1965 (4)

15. Gartnerago obliquum (Stradner, 1963) Noël, 1970 (33)

16. Helicolithus trabeculatus (Górka, 1957) Verbeek, 1977 (2)

17. Loxolithus armilla (Black in Black and Barnes, 1959) Noel, 1965 (33)

18. Lucianorhabdus arcuatus Forchheimer, 1972 (11)

19. Lucianorhabdus cayeuxii Deflandre, 1959 (33)

20. Lithastrinus grillii Stradner, 1962 (11)

21. Marthasterites furcatus (Deflandre in Deflandre \& Fert, 1954) Deflandre, 1959 (4)

22. Manivitella pemmatoidea (Deflandre, 1965) Thierstein, 1971, emend. Black, 1973 (15)

23. Micula staurophora (Gardet, 1955) Stradner, 1963 (33)

24. Placozygus fibuliformis (Reinhardt, 1964) Hoffmann, 1970 (15)

25. Prediscosphaera cretacea (Arkhangelsky, 1912) Gartner, 1968 (26)

26. Prediscosphaera grandis Perch-Nielsen, 1979 (4)

27. Reinhardtites anthophorus (Deflandre, 1959) Perch-Nielsen, 1958 (26)

28. Retecapsa angustiforata Black, 1971 (15)

29. Retecapsa crenulata (Bramlette \& Martini, 1964) Grün, 1975 (33)

30. Russellia bukryi Risatti, 1973 (11)

31. Russellia laswelii Risatti, 1973 (15)

32. Rhagodiscus angustus (Stradner, 1963) Reinhardt, 1971 (26)

33. Rhagodiscus reniformis Perch-Nielsen, 1973 (26)

34. Staurolithites imbricatus (Gartner, 1968) Burnett, 1997a (15)

35. Staurolithites laffittei Caratini, 1963 (26)

36. Tranolithus orionatus (Reinhardt, 1966) Reinhardt, 1966 (33)

37. Watznaueria barnesae (Black, 1959) Perch-Nielsen, 1968 (26)

38. Zeugrhabdotus bicrescenticus (Stover, 1966) Burnett in Gale et al., 1996 (26)

39. Zeugrhabdotus biperforatus (Gartner, 1968) Burnett, 1997a (15)

40. Zeugrhabdotus embergeri (Noël, 1958) Perch-Nielsen, 1984 (15) 

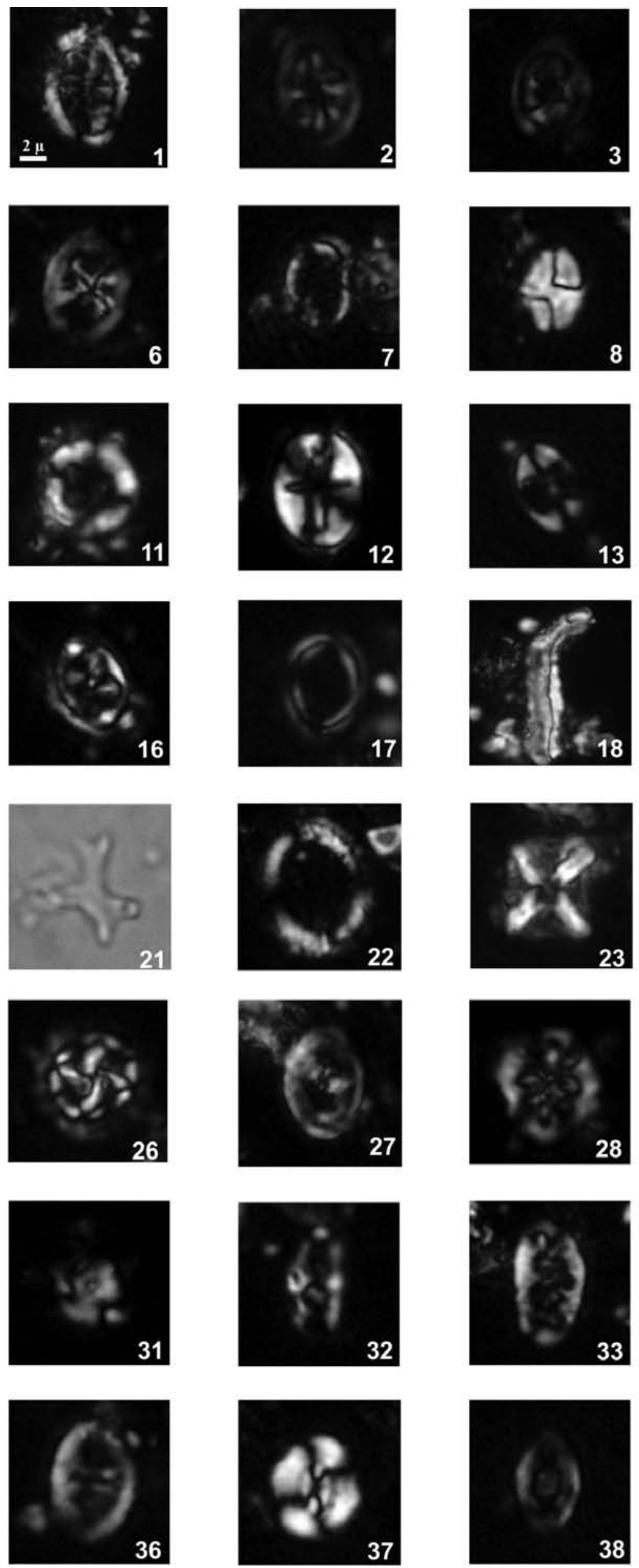
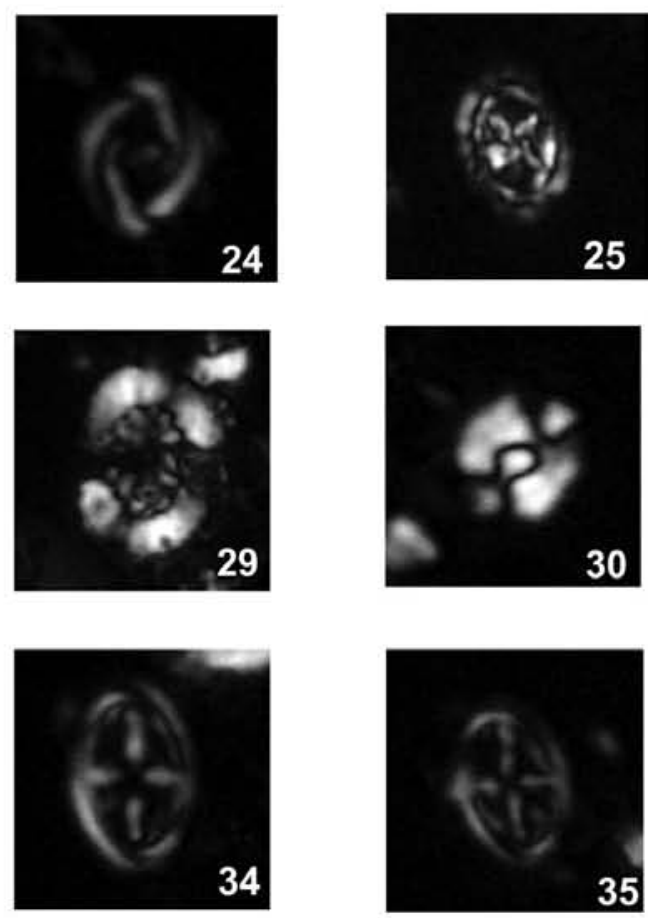

PLATE I
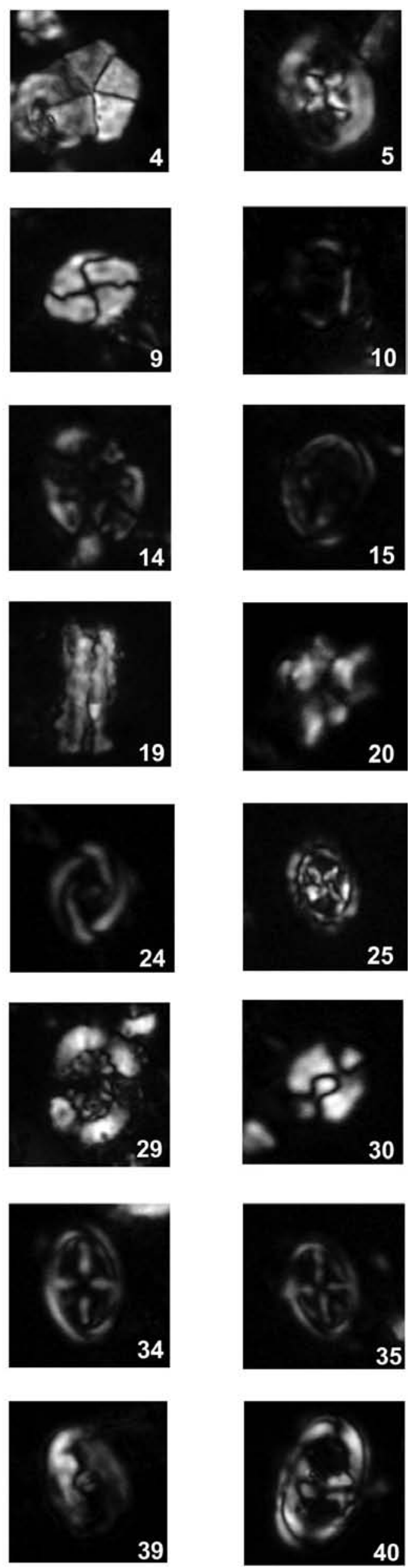

Studia UBB Geologia, 2012, 57 (1), 23 - 32 


\section{APPENDIX 1 \\ (Taxonomic index)}

A full list of all taxa identified in the Băcăinți Valley.

Ahmuellerella octoradiata (Górka, 1957) Reinhardt, 1966

Ahmuellerella regularis (Górka, 1957) Reinhardt \& Górka, 1967

Amphizigus brooksii Bukry, 1969

Arkhangelskiella confusa Burnett, 1997a

Arkhangelskiella cymbiformis Vekshina, 1959

Biscutum constans (Górka, 1957) Black, 1959

Biscutum ellipticum (Górka, 1957) Grün in Grün \& Allemann, 1975

Braarudosphaera bigelowii (Gran \& Braarud, 1935) Deflandre, 1947

Broinsonia enormis (Shumenko, 1968) Manivit, 1971

Broinsonia parca (Stradner, 1963) Bukry, 1969, sp. expansa Wise \& Watkins in Wise, 1983

Calculites obscurus (Deflandre, 1959) Prins \& Sissingh in Sissingh, 1977

Calculites ovalis (Stradner, 1963) Prins \& Sissingh in Sissingh, 1977

Chiastozygus amphipons (Bramlette \& Martini, 1964) Gartner, 1968

Chiastozygus bifarius Bukry, 1969

Chiastozygus litterarius (Górka, 1957) Manivit, 1971

Corollithion signum Stradner, 1963

Cretarhabdus striatus (Stradner, 1963) Black, 1973

Cribrosphaerella ehrenbergii (Arkhangelsky, 1912) Deflandre in Pivetteau, 1952

Cylindralithus crassus Stover, 1966

Cylindralithus sculptus Bukry, 1969

Discorhabdus ignotus (Górka, 1957) Perch-Nielsen, 1968

Eiffelithus eximius (Stover, 1966) Perch-Nielsen, 1968

Eiffelithus gorkae Reinhardt, 1965

Eiffelithus turriseiffelii (Deflandre in Deflandre \& Fert, 1954) Reinhardt, 1965

Eprolithus floralis (Stradner, 1962) Stover, 1966

Gartnerago obliquum (Stradner, 1963) Noël, 1970

Gartnerago segmentatum (Stover, 1966) Thierstein, 1974

Helicolithus anceps (Górka, 1957) Noël, 1970
Helicolithus trabeculatus (Górka, 1957) Verbeek,

1977Kaptnerius magnificus Deflandre, 1959

Lithastrinus grillii Stradner, 1962

Lithastrinus septenarius Forchheimer, 1972

Loxolithus armilla (Black in Black \& Barnes, 1959) Noël, 1965

Lucianorhabdus arcuatus Forchheimer, 1972

Lucianorhabdus cayeuxii Deflandre, 1959

Lucianorhabdus maleformis Reinhardt, 1966

Marthasterites furcatus (Deflandre in Deflandre \& Fert, 1954) Deflandre, 1959

Manivitella pemmatoidea (Deflandre, 1965) Thierstein, 1971, emend. Black, 1973

Microrhabdulus decoratus Deflandre, 1959

Micula staurophora (Gardet, 1955) Stradner, 1963

Placozygus fibuliformis (Reinhardt, 1964) Hoffmann, 1970

Prediscosphaera cretacea (Arkhangelsky, 1912) Gartner, 1968

Prediscosphaera grandis Perch-Nielsen, 1979

Prediscosphaera spinosa (Bramlette \& Martini, 1964) Gartner, 1968

Reinhardtites anthophorus (Deflandre, 1959) Perch-Nielsen, 1958

Retecapsa angustiforata Black, 1971

Retecapsa crenulata (Bramlette \& Martini, 1964) Grün, 1975

Rhagodiscus achlyostaurion (Hill, 1976) Doeven, 1983

Rhagodiscus angustus (Stradner, 1963) Reinhardt, 1971

Rhagodiscus reniformis Perch-Nielsen, 1973

Rhagodiscus splendens (Deflandre, 1953) Verbeek, 1977

Russellia bukryi Risatti, 1973

Russellia laswelii Risatti, 1973

Seribiscutum gaultensis Mutterlose, 1992

Staurolithites imbricatus (Gartner, 1968) Burnett, 1997a

Staurolithites laffittei Caratini, 1963

Tranolithus minimus (Bukry, 1969) Perch-Nielsen, 1984

Tranolithus orionatus (Reinhardt, 1966) Reinhardt, 1966

Watznaueria barnesae (Black, 1959) Perch-Nielsen, 1968

Zeugrhabdotus bicrescenticus (Stover, 1966) Burnett in

Gale et al., 1996

Zeugrhabdotus biperforatus (Gartner, 1968) Burnett, 1997a

Zeugrhabdotus diplogrammus (Deflandre în Deflandre şi

Fert, 1954) Reinhardt, 1965

Zeugrhabdotus embergeri (Noël, 1958) Perch-Nielsen, 1984 